\title{
神経難病医療ネットワークにおける 難病医療専門員のコーデイネート機能
}

\author{
牛 込 三和子, ${ }^{1}$ 友 松 幸 子, ${ }^{2}$ 佐々木 馨 子 ${ }^{1}$ \\ 飯 田苗 恵, ${ }^{3}$ 岡 本 幸 市, ${ }^{4}$ 依田 裕子 ${ }^{5}$ \\ 小 林 良 清, $^{6}$ 早乙女 千恵子 ${ }^{5}$
}

\begin{abstract}
要 旨
【背景と目的】1999 年開始の群馬県神経難病医療ネットワーク推進事業において, 本事業拠点病院の群馬大 学医学部附属病院神経内科外来に配置された神経難病医療専門員 (看護師) の活動を分析し, 難病医療専門員 の調整機能を類型化することを目的とする.【対象と方法】 2 年間の活動記録類を資料とし，事例毎に内容 をコード化し, 類似性を基に集計, 整理・分類した。【結果と結論】神経難病医療専門員は療養者・家族, 保 健師, 医師等から, 療養者 244 人について 601 件の相談があり支援していた。その調整機能は, 療養相談・指 導, 療養者の受入施設確保調整, 拠点病院受診者フォローアップ, 保健所における難病療養者フォローアップ の支援, 地域ケア力向上のための調査・研究・研修, に類型化された. 拠点病院神経内科外来に配置された難 病医療専門員の活動は, 神経難病医療ネットワークが難病療養者のニーズに対応するシステムとして, 有効 に機能していくことを強化している. (Kitakanto Med J 2002 ; 52 : 243〜252)
\end{abstract}

キーワード：難病医療専門員, 神経難病, 外来看護, 拠点病院, 難病医療ネットワーク

\section{背景と目的}

難病対策は, 昭和 47 年に開始されて以来拡充され, 平 成 13 年 5 月現在, 調査研究対象として 118 疾患, 治療研 究対象として 46 疾患について事業が行われている. ${ }^{1}$

難病対策は, 近年, 大きく見直しが行われている. 平成 7 年に公衆衛生審議会成人難病部会難病対策専門委員会 による最終報告, さらに平成 9 年に「今後の難病対策の 具体的方向について」の報告が出され, 重症の難病療養 者の入院または入所施設の確保および在宅療養の支援施

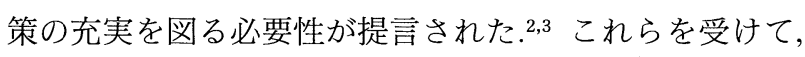
平成 10 年度に大きく制度の見直しが行われ，難病特別 対策推進事業が創設された。この事業には, 都道府県毎 に難病の拠点病院と協力病院を設置する重症難病患者入 院施設確保事業および支援を要する在宅療養者の個々の 実態に応じてきめ細かな支援を行うために，保健所が中 心となって行う難病患者地域支援詨策推進事業がある.
重症難病患者入院施設確保事業では, 難病医療連絡協議 会を設置し，保健師等の資格を有する難病医療専門員を 配置することができる. この事業は, 平成 13 年 11 月現 在 34 都道府県において実施され, 難病医療専門員は 21 県で設置されており，それぞれに取り組みを開始してい る. ${ }^{4 \sim 8}$ 今後, 難病医療専門員の活動は, 難病療養者支援 ネットリークの構留において，その要となることが予測 される。

群馬県における難病対策においては, 平成 9 年, 難病 患者地域支援対策推進事業に訪問相談指導が追加され, 保健所における難病療養者個々への支援を開始, 平成 12 年からは, 在宅療養支援計画策定・評価事業を開始し, 保 健所における難病療養者個々への支援を強化してきた. 平成 11 年 12 月, 重症難病患者入院施設確保事業として, 筇萎縮性側索硬化症等のいわゆる神経難病の療養者に対 する入院施設の確保等を円滑に行なうことを目的に, 群 馬県神経難病医療ネットワーク推進事業を開始した. 図

1 群馬県前橋市昭和町3-39-22 群馬大学医学部保健学科 2 3 群馬県前橋市上沖町 323-1 群馬県立医療短期大学看護学科 群馬県前橋市大手町1-1-1 群馬県保健福祉部保健予防課 


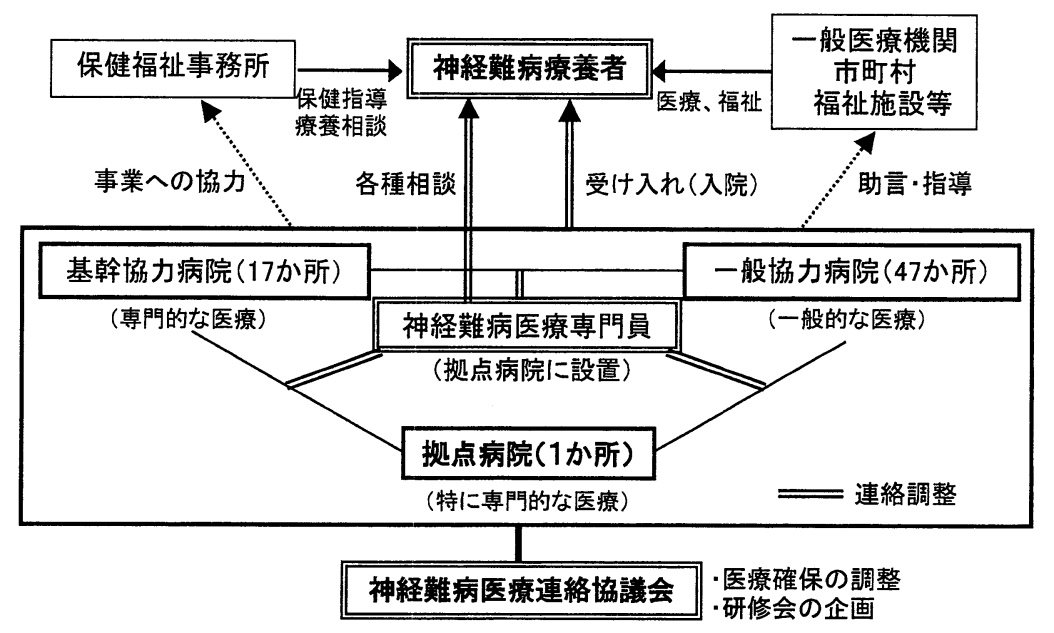

図 1 群馬県神経難病医療ネットワーク体系図

1 亿その体系を示した. 本事業では, 拠点病院である群馬 大学医学部附属病院の神経内科外来に看護師 1 名を神経 難病医療専門員 (以下，専門員とする) として配置した. 専門員は, 神経難病の療養者に対する入院施設の確保等 を円滑に行なうとともに，1）在宅療養に関する各種の相 談に応じる, 2) 必要に応じて保健福祉事務所 (以下, 保健 所とする) 等の関係機関へ患者の紹介や支援要請を行う, 3）拠点病院および基幹・一般協力病院に患者を紹介する, など神経難病療養者および支援機関職員等を支援してい る.

本事業の対象となっている筋萎縮性側索硬化症等の神 経難病は, 疾患が慢性, 進行性で, 病気進行により運動, 構語，嚥下，排尿，呼吸等の機能障害が生じる，そのため, 療養者は日常生活に介助を要する状態, 経管栄養法, 人 工呼吸療法といった医療好置管理状熊で，長期にわたり 療養するという状況になる．これら神経難病で療養する 人々に対するケアシステムは, 発症から終末期まで, 病 気経過にそった支援を, 適切に行うことが必要である. ${ }^{9,10}$ 群馬県における本事業の特徵は, 拠点病院である群馬 大学医学部附属病院神経内科外来に看護職の資格を有す る専門員を配置していることである. 群馬大学医学部附 属病院は, 県内唯一の特定機能病院であり, 受診者は県 内広域に分布している. 神経難病療養者支援ネットワー クにおいては，この広域的な医療機能を有する拠点病院 における療養者フォローアップおよび広域的相談機能を 明らかにし，構築する必要があると考える．そこで, 本研 究では, 約 2 年間の専門員の活動を分析し, 神経難病医 療ネットワークにおける専門員のコーディネート機能を 明らかにすることを目的とした。

対象と方法

\section{1) 対 象}

群馬県神経難病医療ネットワーク推進事業において,
専門員が活動を記録した(1)相談票，(2)個別支援記録，(3) 活動日誌, お5び(4)平成 11 年度, 平成 12 年度群馬県神 経難病医療ネットワーク推進事業活動報告書を調査対象 とした. 対象とした期間は，事業開始の平成 11 年 12 月 から平成 13 年 10 月の 1 年 11 ケ月間である.

\section{2 ) 調查方法}

上記資料をもとに(1)相談者が抱える問題と対応，(2)施 設確保に関する相談と対応，(3)神経難病医療ネットワー ク推進事業の組織である神経難病医療連絡協議会におけ る活動内容について資料収集した，収集した資料は，(1) 相談者が抱える問題と対応，(2)施設確保に関する相談と 対応については, 療養者の概要, 相談者の概要, 相談者の 抱える問題, 対応・支援内容の 4 項目についてコード化 した上で, 類似性を基に集計し整理・分類した。

\section{3 ）分析方法}

相談は，療養者を一般相談者とフォローアップ対象者 に分類,さらに，フォローアップ対象者は拠点病院外来 において専門員がフォローアップしている療養者 (以下, 拠点病院フォローアップ対象者とする), 保健所保健師が フォローアップしている療養者 (以下, 保健所フォロー アップ対象者とする）に分類し，神経難病医療連絡協議 会に扔ける活動内容と統合し, 専門員のコーディネート 機能を類型化した。

\section{4 ）倫理的配慮}

遡及的調査であり，個々人に了解を得ることは困難で あったため，すべての情報について個人を特定できない よう専門員の段階で資料化した上で分析した。

$$
\text { 結果 }
$$

\section{1) 相談の概要}

相談の概要を図 2 に示した. 相談は, 平成 11 年 12 月 の事業開始加平成 13 年 10 月の 1 年 11 ケ月間に, 244 人の療養者について 601 件あった。一般相談者の相談は, 


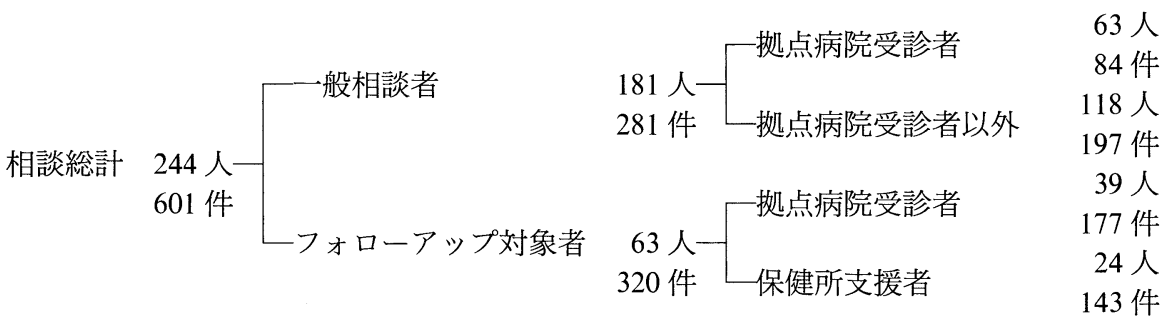

図 2 一般相談者・フォローアップ対象者別相談件数

表 1 療養者の概要

\begin{tabular}{|c|c|c|c|c|c|c|c|}
\hline & & \multirow[b]{2}{*}{ 項 } & \multirow{2}{*}{$\begin{array}{l}\text { 全 体 } \\
\mathrm{n}=244\end{array}$} & \multicolumn{2}{|c|}{ 一般相談者 } & \multicolumn{2}{|c|}{ フォローアップ対象者 } \\
\hline & & & & $\begin{array}{c}\text { 拠点病院 } \\
n=63\end{array}$ & $\begin{array}{c}\text { 拠点病院外 } \\
\mathrm{n}=118\end{array}$ & $\begin{array}{c}\text { 拠点病院 } \\
n=39\end{array}$ & $\begin{array}{c}\text { 保 健 所 } \\
n=24\end{array}$ \\
\hline 年 & 齢 & 平均土標準偏差 (歳) & $58.4 \pm 15.9$ & $54.7 \pm 16.5$ & $60.0 \pm 16.2$ & $56.2 \pm 15.3$ & $64.6 \pm 12.3$ \\
\hline \multirow[t]{3}{*}{ 性 } & 別 & 性 & $123(50.4)$ & 35 & 51 & 20 & 17 \\
\hline & & 性 & $112(45.9)$ & 28 & 58 & 19 & 7 \\
\hline & & 明 & $9(3.7)$ & 0 & 9 & 0 & 0 \\
\hline \multirow[t]{17}{*}{ 疾 } & 患 & 筋萎縮性側索硬化症 & $82(33.6)$ & 14 & 21 & 24 & 23 \\
\hline & & パーキンソン病 & $56(23.0)$ & 13 & 38 & 5 & 0 \\
\hline & & 脊髄小脳変性症 & $32(13.1)$ & 10 & 16 & 5 & 1 \\
\hline & & 多発性硬化症 & $7(2.9)$ & 2 & 5 & 0 & 0 \\
\hline & & 神経線維腫症 & $6(2.5)$ & 5 & 1 & 0 & 0 \\
\hline & & ハンチントン舞踏病 & $3(1.2)$ & 1 & 1 & 1 & 0 \\
\hline & & ウィリス動脈輪閉塞症 & $3(1.2)$ & 0 & 3 & 0 & 0 \\
\hline & & 重症筋無力症 & $3(1.2)$ & 0 & 2 & 1 & 0 \\
\hline & & シャイ・ドレーガー症候群 & $2(0.8)$ & 1 & 1 & 0 & 0 \\
\hline & & 亜急性硬化性全脳炎 & $1(0.4)$ & 0 & 1 & 0 & 0 \\
\hline & & アミロイドーシス & $1(0.4)$ & 0 & 1 & 0 & 0 \\
\hline & & その他の神経系難病 & $8(3.3)$ & 3 & 5 & 0 & 0 \\
\hline & & 進行性筋ジストロフィー & $10(4.1)$ & 3 & 5 & 2 & 0 \\
\hline & & 膠原系疾患 & $6(2.5)$ & 3 & 3 & 0 & 0 \\
\hline & & その他の特定疾患 & $1(0.4)$ & 0 & 1 & 0 & 0 \\
\hline & & その他 & $8(3.3)$ & 4 & 3 & 1 & 0 \\
\hline & & 不 明 & $15(6.1)$ & 4 & 11 & 0 & 0 \\
\hline \multirow{5}{*}{\multicolumn{2}{|c|}{ 受診医療機関 }} & 拠点病院 & $103(42.2)$ & 62 & 0 & 38 & 3 \\
\hline & & 基幹協力病院 & $58(23.8)$ & 0 & 43 & 1 & 14 \\
\hline & & 一般協力病院 & $29(11.9)$ & 0 & 22 & 0 & 7 \\
\hline & & その他 & $35(14.3)$ & 1 & 34 & 0 & 0 \\
\hline & & 不 明 & $19(7.8)$ & 0 & 19 & 0 & 0 \\
\hline \multirow{4}{*}{\multicolumn{2}{|c|}{ 療養場所 }} & 自宇 & $182(74.6)$ & 54 & 81 & 38 & 9 \\
\hline & & 医療機関 & $53(21.7)$ & 9 & 28 & 1 & 15 \\
\hline & & 施設 & $3(1.2)$ & 0 & 3 & 0 & 0 \\
\hline & & 不 & $6(2.5)$ & 0 & 6 & 0 & 0 \\
\hline
\end{tabular}

単位: 人, ( ) 内は \%

181 人について 281 件で，内訳は拠点病院受診者が 63 人 84 件，拠点病院受診者以外が 118 人 197 件であった。 フォローアップ対象者の相談は 63 人について 320 件で, 拠点病院フォローアップ対象者 39 人 177 件, 保健所 フォローアップ対象者 24 人 143 件であった. 全相談 601 件の相談方法は, 電話 336 件, 面接 249 件, 電子メール 13 件, ファクシミリ 3 件であった.

相談の対象となった療養者の概要を表 1 に示した. 相 談対象療養者のうち神経難病療養者の疾患は筋萎縮性側 索硬化症 82 人 $(33.6 \%)$, パーキンソン病 56 人 $(23.0 \%)$,
脊髄小脳変性症 32 人 $(13.1 \%)$ の順で多く,この 3 疾患 で全体の約 7 割を占めていた. 受療医療機関は, 拠点病 院 103 人 (42.2\%), 基幹協力病院 58 人 $(23.8 \%)$, 一般協 力病院 29 人 $(11.9 \%)$ の順であった. 療養場所は, 自宅 182 人 $(74.6 \%)$, 医療機関 53 人 $(21.7 \%)$, 施設 3 人 (1.2\%) であった. 初回相談者の概要を表 2 に示した, 本 人が 108 人 $(44.3 \%)$ で最も多く，次いで配偶者 39 人 $(16.0 \%)$, 子 20 人 $(8.2 \%)$, 親 10 人 $(4.1 \%)$ などであった. 支援機関からの相談者は, 保健所保健師 31 人 (12.7\%), 病院医師 6 人 (2.5\%), 訪問看護師 3 人 $(1.2 \%)$ の順で 
表 2 初回相談者

\begin{tabular}{|c|c|c|c|c|c|c|}
\hline & \multirow[b]{2}{*}{ 項 } & \multirow{2}{*}{$\begin{array}{l}\text { 全 体 } \\
\mathrm{n}=244\end{array}$} & \multicolumn{2}{|c|}{ 一 般 相 談 者 } & \multicolumn{2}{|c|}{ フォローアップ対象者 } \\
\hline & & & $\begin{array}{c}\text { 拠点病院 } \\
n=63\end{array}$ & $\begin{array}{c}\text { 拠点病院外 } \\
\mathrm{n}=118\end{array}$ & $\begin{array}{c}\text { 拠点病院 } \\
\mathrm{n}=39\end{array}$ & $\begin{array}{c}\text { 保 健 所 } \\
\mathrm{n}=24\end{array}$ \\
\hline \multirow[t]{19}{*}{ 初回相談者 } & 本 人 & $108(44.3)$ & 41 & 40 & 26 & 1 \\
\hline & 配 偶 者 & $39(16.0)$ & 6 & 28 & 2 & 3 \\
\hline & 子 & $20(8.2)$ & 4 & 12 & 4 & 0 \\
\hline & 親 & $10(4.1)$ & 5 & 3 & 2 & 0 \\
\hline & 兄弟姉妹 & $9(3.7)$ & 1 & 5 & 1 & 2 \\
\hline & 家族・親戚 & $6(2.5)$ & 2 & 3 & 1 & 0 \\
\hline & 患 者 会 & $3(1.2)$ & 0 & 2 & 0 & 1 \\
\hline & 知人 & $1(0.4)$ & 1 & 0 & 0 & 0 \\
\hline & 保健所保健師 & $31(12.7)$ & 1 & 13 & 2 & 15 \\
\hline & 病院医師 & $6(2.5)$ & 0 & 3 & 1 & 2 \\
\hline & 訪問看護師 & $3(1.2)$ & 0 & 3 & 0 & 0 \\
\hline & 市町村保健師 & $1(0.4)$ & 0 & 1 & 0 & 0 \\
\hline & 病院看護師 & $1(0.4)$ & 0 & 1 & 0 & 0 \\
\hline & 在宅介護支援センター看護師 & $1(0.4)$ & 1 & 0 & 0 & 0 \\
\hline & ケアマネージャー & $1(0.4)$ & 1 & 0 & 0 & 0 \\
\hline & 理学療法士 & $1(0.4)$ & 0 & 1 & 0 & 0 \\
\hline & 作業療法士 & $1(0.4)$ & 0 & 1 & 0 & 0 \\
\hline & 医療ソーシャルワーカー & $1(0.4)$ & 0 & 1 & 0 & 0 \\
\hline & 事 & $1(0.4)$ & 0 & 1 & 0 & 0 \\
\hline
\end{tabular}

単位: 人, ( ) 内は\%

表 3 相談全件数からみた相談者の内訳

\begin{tabular}{|c|c|c|c|c|}
\hline \multicolumn{2}{|c|}{ 療養者等 } & \multicolumn{3}{|c|}{ 支援機関 } \\
\hline 本人との関係 & 件数 （\%) & \multicolumn{2}{|r|}{ 職 種 } & 件数 （\%) \\
\hline \multirow{16}{*}{$\begin{array}{l}\text { 本 人 } \\
\text { 配 偶 者 } \\
\text { 子 } \\
\text { 親 } \\
\text { 兄弟姉妹 } \\
\text { 嫁 } \\
\text { その他の家族等 } \\
\text { 知 人 } \\
\text { 患 者 会 }\end{array}$} & $193(48.7)$ & \multirow[t]{5}{*}{ 看 護 職 } & 保健所保健師 & $150(73.2)$ \\
\hline & $99(25.0)$ & & 市町村保健師 & $2(1.0)$ \\
\hline & \multirow{2}{*}{$\begin{array}{l}35(8.8) \\
30(7.6)\end{array}$} & & 訪問看護師 & $6(2.9)$ \\
\hline & & & 介護支援センター看護師 & $4(1.9)$ \\
\hline & \multirow{12}{*}{$\begin{array}{rll}21 & ( & 5.3) \\
6 & ( & 1.5) \\
7 & ( & 1.8) \\
1 & ( & 0.3) \\
4 & ( & 1.0)\end{array}$} & & 病院看護師 & $3(1.5)$ \\
\hline & & \multirow[t]{2}{*}{ 医師 } & 病院医師 & \multirow{2}{*}{$\begin{array}{rr}24 & (11.7) \\
1 & (\quad 0.5) \\
\end{array}$} \\
\hline & & & 保健所医師 & \\
\hline & & \multirow[t]{3}{*}{ その他の医療職 } & 理学療法士 & $1(0.5)$ \\
\hline & & & 作業療法士 & $1(0.5)$ \\
\hline & & & 言語療法士 & $1(0.5)$ \\
\hline & & \multirow[t]{4}{*}{ 福 祉 職 } & 介護支援専門員 & $4(1.9)$ \\
\hline & & & 医療ソーシャルワーカー & $4(1.9)$ \\
\hline & & & 児童相談所心理士 & $1(0.5)$ \\
\hline & & & 老人保健施設相談員 & $1(0.5)$ \\
\hline & & \multirow[t]{2}{*}{ その他 } & 事務 & $1(0.5)$ \\
\hline & & & 不明 & $1(0.5)$ \\
\hline 計 & $396(100.0)$ & \multicolumn{2}{|l|}{ 計 } & $205(100.0)$ \\
\hline
\end{tabular}

あった。

相談全件数からみた相談者の内訳を表 3 に示した. 療 養者等からの相談 396 件は, 本人 193 件 (48.7\%), 配偶者 99 件 $(25.0 \%)$ で 7 割を占めていた. 支援機関からの相談 205 件は, 保健所保健師 150 件 (73.2\%), 市町村保健師 2
件 $(1.0 \%)$, 訪問看護師 6 件 $(2.9 \%)$ 等看護職が約 8 割を 占め, 医師では, 病院医師 24 件 (11.7\%), 保健所医師 1 件 $(0.5 \%)$, 福祉職では，介護支援専門員 4 件 $(1.9 \%)$, 医療 ソーシャルワーカー4 件 (1.9\%) などであった. 
表 4 相談者がかかえる問題

\begin{tabular}{|c|c|c|c|c|c|}
\hline & \multirow[b]{2}{*}{ 相 談 内 容 } & \multirow[b]{2}{*}{ 全 体 } & \multirow{2}{*}{$\begin{array}{c}\text { 一般相談者 } \\
n=181\end{array}$} & \multicolumn{2}{|c|}{ フォローアップ対象者 } \\
\hline & & & & $\begin{array}{c}\text { 拠点病院 } \\
n=39\end{array}$ & $\begin{array}{l}\text { 保健所 } \\
\mathrm{n}=24\end{array}$ \\
\hline \multirow[t]{12}{*}{ 療養者等 } & 病気・治療・薬 & $90(28.0)$ & 55 & 28 & 7 \\
\hline & 外来受診時の相談全般 & $64(19.9)$ & 28 & 34 & 2 \\
\hline & 制度・サービス利用法 & $57(17.8)$ & 43 & 14 & 0 \\
\hline & 受療について & $36(11.2)$ & 29 & 5 & 2 \\
\hline & 在宅療養困難時の療養施設 & $23(7.2)$ & 20 & 3 & 0 \\
\hline & 長期入院中の転院施設 & $20(6.2)$ & 19 & 1 & 0 \\
\hline & 在宅療養移行 & $8(2.5)$ & 3 & 1 & 4 \\
\hline & 社会的ハンディーキャップ & $7(2.2)$ & 6 & 1 & 0 \\
\hline & 拠点病院主治医連絡空口 & $6(1.9)$ & 0 & 4 & 2 \\
\hline & 介護機器類・介護方法など & $3(0.9)$ & 2 & 1 & 0 \\
\hline & その他 & $7(2.2)$ & 5 & 2 & 0 \\
\hline & 計 & $321(100.0)$ & 210 & 94 & 17 \\
\hline \multirow[t]{12}{*}{ 支援機関 } & 支援全般 & $42(33.3)$ & 14 & 10 & 18 \\
\hline & 看護・ケアの方法 & $16(12.7)$ & 10 & 0 & 6 \\
\hline & 受入施設の確保 & $14(11.0)$ & 12 & 1 & 1 \\
\hline & 告知・治療法選択の意思決定 & $10(7.9)$ & 4 & 0 & 6 \\
\hline & 医療・介護機器類に関すること & $10(7.9)$ & 2 & 1 & 7 \\
\hline & 拠点病院主治医連絡空口 & $10(7.9)$ & 0 & 5 & 5 \\
\hline & 在宅人工呼吸療法移行 & $9(7.1)$ & 1 & 1 & 7 \\
\hline & 拠点病院退院時の退院調整 & $6(4.8)$ & 3 & 3 & 0 \\
\hline & ネットワーク & $4(3.2)$ & 4 & 0 & 0 \\
\hline & その他の医療処置の在宅移行支援 & $1(0.8)$ & 1 & 0 & 0 \\
\hline & その他 & $4(3.2)$ & 0 & 4 & 0 \\
\hline & 計 & $126(100.0)$ & 51 & 25 & 50 \\
\hline
\end{tabular}

単位: 件, ( )内は\% (重複あり)

\section{2 ）相談者がかかえる問題}

相談者がかかえる問題全件を内容別に整理・分類し, 表 4 に示した. ここでは, 相談者が数回相談を行った場 合でも，内容が同一のものについては 1 件として集計し た。

\section{（1） 療養者等の相談者がかかえる問題}

療養者等からの相談は, 一般相談者から 210 件, 拠点 病院フォローアップ対象者から 94 件, 保健所フォロー アップ対象者から 17 件であった.

療養者等の相談者がかかえる問題として, 病気・治療・ 薬 90 件 $(28.0 \%)$, 外来受診時の相談全般 64 件 (19.9\%), 制度・サービス利用法 57 件 (17.8\%) の順で多かった. 外 来受診時の相談全般には, 療養者の状態把握など専門員 による主体的な面接が行われていた. 本事業の本来の目 的である施設確保に関する相談は，在宅療養困難時の療 養施設 23 件 $(7.2 \%)$ ，長期入院中の転院施設 20 件 (6.2\%) であった.

\section{（2）支援機関相談者がかかえる問題}

支援機関職員からの相談件数は，一般相談者について 51 件, 拠点病院フォローアップ対象者について 25 件, 保 健所フォローアップ対象者について 50 件であった.

支援機関相談者がかかえる問題は，支援全般 42 件 $(33.3 \%)$, 看護・ケアの方法 16 件 $(12.7 \%)$, 受入施設の確 保 14 件 (11.0\%) の順で多かった.
また，拠点病院主治医連絡空口としての相談 10 件 $(7.9 \%)$, 拠点病院退院時の退院調整 6 件 (4.8\%) の相談 があった。

\section{3 ）相談への対応と支援}

\section{(1) 一般相談者への対応と支援}

一般相談者からの相談への対応を表 5 に示した. 専門 員は, 問題の状況を聴き取り，その内容に応じて支援し ていた. 対応は, 受入施設の確保 10 件 $(3.9 \%)$, 主治医へ 連絡 10 件 $(3.9 \%)$, 保健所・その他の支援機関と連携 22 件 $(8.5 \%)$ などであった. また, 主治医への相談を勧奨 21 件 $(8.1 \%)$ ，ネットワークの紹介 40 件 (15.4\%)，および サービス利用の手続き方法, 食事の工夫，リハビリ方法 など専門的かつ具体的な情報提供・助言の対応が 148 件 (57.1\%) あった。

表 5 相談への対応 1 - 一般相談者

\begin{tabular}{|c|c|}
\hline 対 応 方 法 & 件数 （\%) \\
\hline 受入施設の確保 & $10(3.9)$ \\
\hline 主治医へ連絡 & $10(3.9)$ \\
\hline 保健所・その他の支援機関と連携 & $22(8.5)$ \\
\hline 主治医への相談を勧奨 & $21(8.1)$ \\
\hline ネットワークの紹介 & $40(15.4)$ \\
\hline 情報提供・助言 & $148(57.1)$ \\
\hline その他 & $8(3.1)$ \\
\hline 計 & $259(100.0)$ \\
\hline
\end{tabular}


表 6 相談への対応 2 一拠点病院フォローアップ対象者

対 応 方 法件数 $(\%)$

\begin{tabular}{|c|c|}
\hline 主治医へ連絡 & $7(9.3)$ \\
\hline 保健所・その他の支援機関と連携 & $18(24.0)$ \\
\hline 主治医への相談を勧奨 & $2(2.7)$ \\
\hline ネットワークの紹介 & $10(13.3)$ \\
\hline 情報提供・助言 & $38(50.7)$ \\
\hline 計 & $75(100.0)$ \\
\hline
\end{tabular}

表 8 施設確保に関する相談内容と支援方法 50 人 53 件

\begin{tabular}{llr}
\hline & & 件数 \\
\hline 相談内容 & 長期入院中の転院施設 & 26 \\
& 在宅療養困難時の療養施設 & 27 \\
\hline 支援方法 & 施設確保 & 11 \\
& 主治医へ連絡 & 2 \\
& 保健所・その他の支援機関と連携 & 5 \\
& 主治医への相談を勧奨 & 14 \\
& ネットワーク紹介等の情報提供 & 21 \\
\hline
\end{tabular}

表 7 相談への対応 3 一保健所フォローアップ対象者

\begin{tabular}{|c|c|c|c|c|c|c|c|c|c|c|c|c|}
\hline \multirow[b]{2}{*}{$\begin{array}{l}\text { 保 } \\
\text { 健 } \\
\text { 所 }\end{array}$} & \multirow[b]{2}{*}{ 事例 } & \multirow[b]{2}{*}{ 疾患 } & \multirow[b]{2}{*}{$\begin{array}{c}\text { 初回相談機関 } \\
\text { (職種) }\end{array}$} & \multirow[b]{2}{*}{ 初回相談課題 } & \multirow[b]{2}{*}{$\begin{array}{c}\text { 支 } \\
\text { 援 } \\
\text { 期 } \\
\text { 間 } \\
\text { 恶 }\end{array}$} & \multicolumn{7}{|c|}{ 専門員による支援の内容 } \\
\hline & & & & & & $\begin{array}{l}\text { 情 } \\
\text { 報 } \\
\text { 提 } \\
\text { 供 }\end{array}$ & $\begin{array}{l}\text { 主 } \\
\text { 治 } \\
\text { 医 } \\
\text { 連 } \\
\text { 絡 }\end{array}$ & $\begin{array}{l}\text { 電 } \\
\text { 話 } \\
\text { 面 } \\
\text { 接 }\end{array}$ & $\begin{array}{l}\text { 病 } \\
\text { 院 } \\
\text { 同 } \\
\text { 行 }\end{array}$ & $\begin{array}{l}\text { 自 } \\
\text { 宅 } \\
\text { 同 } \\
\text { 行 }\end{array}$ & $\begin{array}{l}\text { 開 調 } \\
\text { 催 整 } \\
\text { 助会 } \\
\text { 言 議 }\end{array}$ & $\begin{array}{r}\text { 出 調 } \\
\text { 整 } \\
\text { 会 } \\
\text { 席議 } \\
\end{array}$ \\
\hline \multirow[t]{9}{*}{ A } & 1 & ALS & 保健所 (保健師) & HMV 移行 & 20 & 0 & 0 & 0 & 0 & 0 & 0 & 0 \\
\hline & 2 & ALS & 拠点病院 (医師) & 告知時の家族支援 & 11 & 0 & $\bigcirc$ & 0 & $\bigcirc$ & $\bigcirc$ & 0 & 0 \\
\hline & 3 & ALS & 保健所 (保健師) & HMV 移行 & 10 & 0 & 0 & 0 & 0 & & & \\
\hline & 4 & ALS & 保健所 (保健師) & 医療処置意思決定 & 7 & 0 & 0 & & & & & \\
\hline & 5 & ALS & 保健所 (保健師) & 医療処置意思決定 & 7 & 0 & $\bigcirc$ & & & & & \\
\hline & 6 & ALS & 保健所 (保健師) & 呼吸器装着意思決定 & 4 & 0 & 0 & & & & & \\
\hline & 7 & ALS & 保健所 (保健師) & 受療 & 4 & 0 & & & & & & \\
\hline & 8 & ALS & 保健所 (保健師) & 受療 & 1 & 0 & & & & & & \\
\hline & 9 & ALS & 保健所 (保健師) & 告知時の家族支援 & 1 & 0 & 0 & $\bigcirc$ & & & & \\
\hline \multirow[t]{7}{*}{$\mathrm{B}$} & 10 & ALS & 病院 (医師) & HMV 移行 & 16 & 0 & 0 & 0 & O & 0 & 0 & 0 \\
\hline & 11 & ALS & 病院 (医師) & IVH 在宅移行 & 5 & 0 & 0 & 0 & 0 & $\bigcirc$ & $\bigcirc$ & $\bigcirc$ \\
\hline & 12 & ALS & 保健所 (保健師) & 医療処置意思決定 & 13 & 0 & & $\bigcirc$ & & $\bigcirc$ & 0 & 0 \\
\hline & 13 & ALS & 保健所 (保健師) & 呼吸器装着意思決定 & 4 & 0 & $\bigcirc$ & 0 & & 0 & & \\
\hline & 14 & ALS & 保健所 (保健師) & 医療処置意思決定 & 4 & 0 & & $\bigcirc$ & & 0 & & \\
\hline & 15 & SCD & 保健所 (保健師) & HMV 移行 & 2 & $\bigcirc$ & $\bigcirc$ & $\bigcirc$ & $\bigcirc$ & $\bigcirc$ & & \\
\hline & 16 & ALS & 保健所 (保健師) & HMV 移行 & 1 & 0 & & 0 & $\bigcirc$ & & & \\
\hline \multirow[t]{3}{*}{$\mathrm{C}$} & 17 & ALS & 保健所 (保健師) & HMV 移行 & 23 & 0 & 0 & 0 & $O$ & 0 & 0 & 0 \\
\hline & 18 & ALS & 保健所 (保健師) & 呼吸器装着意思決定 & 13 & $\bigcirc$ & 0 & $\bigcirc$ & $\bigcirc$ & 0 & & \\
\hline & 19 & ALS & 保健所 (保健師) & 医療処置意思決定 & 7 & 0 & & 0 & & 0 & & \\
\hline $\mathrm{D}$ & 20 & ALS & 保健所 (保健師) & HMV 移行 & 1 & 0 & & $\bigcirc$ & 0 & 0 & & \\
\hline$E$ & 21 & ALS & 保健所 (保健師) & HMV 移行 & 11 & 0 & 0 & 0 & 0 & 0 & 0 & 0 \\
\hline $\mathrm{F}$ & 22 & ALS & 保健所 (保健師) & HMV 移行 & 6 & 0 & & 0 & & 0 & $U$ & 0 \\
\hline $\mathrm{G}$ & 23 & ALS & 保健所 (保健師) & HMV 移行 & 6 & 0 & & 0 & & & & \\
\hline $\mathrm{H}$ & 24 & ALS & 保健所 (保健師) & 呼吸器装着意思決定 & 6 & $\mathrm{O}$ & $\bigcirc$ & 0 & $\bigcirc$ & $\bigcirc$ & O & 0 . \\
\hline
\end{tabular}

注) ALS：筋萎縮性側索硬化症 SCD：春髄小脳変性症 HMV：在宅人工呼吸療法 呼吸器: 経気管陽圧式人工呼吸器 IVH : 中心静脈栄養法

\section{(2) 拠点病院フォローアップ対象者への支援}

拠点病院フォローアップ対象者への支援を表 6 に示し た. 地域主治医へ連絡 7 件 (9.3\%), 保健所 - その他の支 援機関と連携 18 件 (24.0\%), 地域主治医へ相談を勧奨 2 件 $(2.7 \%)$, ネットワークの紹介 10 件 $(13.3 \%)$, 専門的か つ具体的な情報提供・助言 38 件 (58.7\%) であった.

\section{(3) 保健所フォローアップ対象者への支援}

保健所フォローアップ対象者 24 人について, 初回相 談時の課題と支援を表 7 に示した. 事例番号は同一保健 所内では，支援開始時期により順位を付した，支援期間 は初回相談から調査時点までの月数を示した. 死亡例に ついては, 死亡時までの期間を示した。

保健所フォローアップ対象者の疾患は, 筋萎縮性側索
硬化症 23 人 $(95.8 \%)$, 春髄小脳変性症 1 人 $(4.2 \%)$ で, 初 回相談機関・職種は, 保健所保健師 21 人 $(87.5 \%)$, 病院 医師 2 人 $(8.3 \%)$, 拠点病院医師 1 人 $(4.2 \%)$ であった. 初 回相談時の課題は, 在宅人工呼吸療法移行 10 人 (41. $7 \%)$, 医療処置意思決定 5 人 $(20.8 \%)$, 人工呼吸器装着意 思決定 4 人 $(16.7 \%)$, 告知時の家族支援 2 人 $(8.3 \%)$, 受 療 2 人 $(8.3 \%)$, 中心静脈栄養療法在宅移行 1 人 $(4.2 \%)$ であった. 専門員は, 情報提供, 主治医への連絡, 電話・ 面接, 病院への同行, 自宅への同行, 調整会議開催の助言, 調整会議への出席の方法で保健所保健師によるフォロー アップを支援していた. 複数の療養者について協働支援 を経験した A・B・C 保健所については, 支援事例の積み 重ねとともに, 専門員の支援の種類が減っていた. 
表 9 調査, 研修

平成 11 年 12 月一平成 13 年 11 月

\begin{tabular}{|c|c|c|c|}
\hline & 調査・研修内容 & 対 & 回数 \\
\hline \multirow[t]{3}{*}{ 調査 } & 平成 11 年度 ALS 患者療養状況調査 & \multirow{3}{*}{$\begin{array}{l}\text { 県内 } 143 \text { 病院・県外 } 4 \text { 病院の医師 } \\
\text { 県内 } 143 \text { 病院 } \\
\text { 県内 } 89 \text { 訪問看護ステーション }\end{array}$} & 1 \\
\hline & 平成 12 年度 ALS 等神経難病診療状況調査 & & 1 \\
\hline & 平成 12 年度神経難病患者訪問看護実施状況調査 & & 1 \\
\hline \multirow[t]{7}{*}{ 研修等 } & 神経難病医療研修会 企画・運営 & 医師・看護師・保健師 & 3 \\
\hline & 神経難病患者療養支援研修会 企画・運営 & 医師・看護師・保健師 & 3 \\
\hline & 訪問看護婦養成講習会 (難病担当) 講師 & 看護師 & 2 \\
\hline & 難病患者等ホームヘルパー養成研修会 講師 & ホームヘルパー & 2 \\
\hline & 日本 ALS 協会群馬県支部総会＼cjkstart講師 & 患者・家族・医療従事者 & 1 \\
\hline & 身体障害者療護施設看護師学習会 講師 & 施設看護師・ケアワーカー & 5 \\
\hline & 難病患者地域支援事例検討会 & 保健師 & 10 \\
\hline
\end{tabular}

\section{4 ）施設確保に関する相談と対応}

相談全件のうち, 施設確保に関する相談の内容と対応 を抽出し表 8 に示した. 相談内容は, 在宅療養困難時の 療養施設について 27 件，長期入院中の転院施設につい て 26 件であった.これらの相談への対応は, 受け入れ施 設確保の調整 11 件, 主治医へ連絡 2 件, 保健所・その他 の支援機関と連携 5 件, 主治医への相談の勧奨 14 件, 本 事業の紹介や情報提供 21 件であった. 全ての相談者に 対し, 相談の継続が可能であることを伝えていた。

\section{5 ）神経難病医療ネットワーク推進事業の組織である神 経難病医療連絡協議会における活動内容}

専門員が, 本事業の一環として県保健予防課と協力し て活動した内容を, 表 9 に示した.

\section{(1) 療養者に関する実態把握}

本事業の開始にあたり, 県内の筋萎縮性側索硬化症患 者療養状況調査に参加していた. 調査は, 県内 143 病院 および診療所等の医師，県外の隣接する 4 病院の医師を 対象にした郵送法による質問紙調査である. 調査の結果, 病状悪化時の受入施設が未定である療養者 21 人全例, および介護困難時の受入施設が未定である療養者 32 人 中 30 人がネットワークによる調整を希望していた. 専 門員は, 調整を希望すると回答のあった療養者について, 医療機関の主治医と連絡をとり，連携を図っていた。

\section{（2）地域ケアカ向上のための活動}

専門員は, 本事業が主催する年 2 回の神経難病医療連 絡協議会における報告や問題提起, および調査, 研修等 の活動を行っていた.

調査として, 筋萎縮性側索硬化症等神経難病療養者の 療養環境の整備・検討を目的に，県内 143 病院を対象に 筋萎縮性側索硬化症等神経難病診療状況調査の実施, 神 経難病療養者の在宅療養の整備・検討を目的に，県内 89 訪問看護ステーションを対象に, 神経難病患者訪問看護 実施状況調査を実施していた。

研修として, 医師・看護師・保健師を対象とした神経難 病医療研修会, 神経難病患者療養支援研修会の企画運営 を各 3 回行っていた，また，看護師対象の訪問看護婦養
成講習会 (難病担当), およびホームヘルパー対象の難病 患者等ホームヘルパー養成研修会における講師を各 2 回 行っていた.さらに, 日本 ALS 協会群馬県支部総会にお ける療養者・家族・医療従事者を対象とした講演, 筋萎縮 性側索硬化症療養者の受入施設である身体障害者療護施 設の看護師・ケアワーカーを対象とした学習会講師，お よび保健所保健師の難病患者地域事例検討会への参加を 行っていた。

さらに, 本事業の成果をもとに, 他県における難病医 療ネットワーク関連の総会および研修会, 厚生労働省特 定疾患医療従事者研修会における講師，関連する学会， 研究会や研究班会議での発表を行っていた。

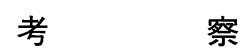

群馬県神経難病医療ネットワークにおける神経難病医 療専門員の 1 年 11 ケ月間の活動を分析した。神経難病医 療専門員の活動は，一般療養相談，受入施設確保に関す る支援, 拠点病院受診者のフォローアップ, 保健所にお ける難病療養者フォローアップ支援, 地域ケア力向上の ための活動に分類された.

療養相談において療養者等がかかえている問題は, 病 気・薬・治療や制度・サービス利用法, 受療についてで あった.このような療養相談が多いことの背景として， 県内で神経内科を開設している医療機関は，基幹協力病 院 17 医療機関のうち 7 医療機関, 一般協力病院 47 医療 機関のうち 7 医療機関であり, ${ }^{11}$ 療養者が身近に情報を 得ることが困難であることが推察される.また，地域に おける難病療養者の支援ネットワークの中核となること を期待されている保健所において難病療養者の支援経験 が少なく,ケアのノウハウがまだ蓄積されていないこと が推察される. 東京都難病医療相談事業についての調査 では, ${ }^{12,13}$ 相談事業の担当者が専門医と都医師会担当委 員の医師，保健師・看護師，メディカルソーシャルワー カーといった保健・医療・福祉の難病専門スタッフであ ることから，広域的特性による第三者的存在としての機 能を果たしていることが報告されている. 本県では, 神 
経難病ケアについての専門的な知識・技術の蓄積, 普及 が十分ではなく, 療養相談に対する専門的・具体的な情 報提供やセカンドオピニオンとしての機能が求められて いる. 調査対象となった専門員は, 病院での看護経験に 加えて, 神経難病在宅看護の経験を有し,この領域での 知識と技術を有している.これらの知識と技術に基づい た助言, 指導が, 難病療養者に期待されている機能とい える.

他県の同事業の調査報告によると療養者の生活上の相 談は在宅医療についてや，在宅療養へ移行する際の調整 が多いとの報告がある.4,5 群馬県では, 県内唯一の特定機 能病院である大学病院が拠点病院となっており, その神 経内科外来に看護職の専門員が配置されていることが, 療養相談の内容にも反映していると考える.

本事業の本来の目的である施設確保に関する相談と対 応では, 必要に応じ直接受入施設を確保するための調整 の役割を発揮し, その他の相談事例では, 相談者に対し 主治医への相談を勧め, その方法を具体的に助言するな ど相談者自らの行動を後押しするとともに，その後の相 談も継続して可能であることを伝えていた．このような 支援は, 相談者の問題解決力の獲得を助けるものであり, 相談者自らが医師との関係のなかで解決できるょう, 長 期療養過程における療養姿勢の確立を支援しているとい える.このような支援は，専門員が看護職であることに よるものと考える.

拠点病院受診者への支援については, 受診者の状態に 応じて主体的に面接していた. 特に筋萎縮性側索硬化症 は進行が早い病型もあることから，早期からのフォロー アップが必要である. 専門員は, 病状の淮行に合わせて 個別支援記録を作成し，フォローアップ対象者として， 外来受診時継続支援をしていた．これは，拠点となる専 門医療機関における外来看護機能といえる.

県内の神経難病療養者の多くは, 診断確定を目的に大 学病院を受診し, 診断確定後, あるいは病状が進行し外 来通院が困難になる時期に, 居住地に近い基幹協力病院 や一般協力病院で診療を受ける例が多い. 専門員は, 受 診医療機関の変更にともない保健所や地域支援機関への 連携を行い，療養者ケアの地域への橋渡しという流れを 創り出しているといえる.さらに，保健所をはじめとす る支援機関から拠点病院主治医への仲介や受診時の連絡 などを行っており，地域における双方向の連携公口とし て機能しているといえる.

米国では, メディカルセンター内に ALS クリニック を開設しているところがあり，そこでは，患者に対し神 経内科専門医とともに多くの専門職が総合的なケアを提 供している. ${ }^{14,15}$ チームに常駐する構成員は, 専門医の他, 看護コーディネーター, 理学療法士, 作業療法士, 栄養士,
言語療法士，ソーシャルワーカーである. 看護コーディ ネーターは, ALS チームの多様な専門職, 患者と家族ま たは介護者, 社会資源の活用への連絡調整として活動し, 病気の説明やパンフレットの提供, 身体・精神活動のサ ポートと話し合いの場の提供, 残存機能の活用と生活の 質のための患者教育などを行っている. 有効な経験を備 えた看護コーディネーターは, チームの要として機能し ている. 専門員の拠点病院受診者への支援は, ALS 看護 コーディネーターと共通する機能であると考える.

保健所における難病療養者フォローアップへの支援で は, 支援要請に対し状況に応じて支援していた. 県内保 健所における難病療養者支援は平成 9 年に開始したとこ ろであり, その経験は少ない. 神経系難病の代表的な疾 患である筋萎縮性側索硬化症についてみると, 平成 13 年 3 月現在の医療費公費負担受給者数は県内で 99 人, 保健所ごとにみると 2 2 2 人であり, 1 例づつ経験を積 み上げてきている状況といえる. 専門員は, このような 県内の難病療養者支援の現状の中で, 地域における療養 者支援機関の支援のあり方を難病療養者のフォローアッ プシステムの一環として捉え, 個々の療養者フォロー アップの過程を支援している. 保健所保健師との基幹協 力病院への同行訪問, 主治医への連絡, 調整会議への出 席などの支援を通して, 保健所と地域の基幹協力病院を 核とした地域ごとのネットワークを，それぞれの地域の ケアカを考慮した上で，その構築を支援しているといえ る.

療養者の実態把握に関する活動では, 実態調査により 県内の筋萎縮性側索硬化症療養者の療養状況及び受入施 設の準備状況を把握するとともに，この調査結果を踏ま えて主体的に主治医と連携を図り, 療養者の入院施設確 保のための基盤づくりを行っていた.

研修活動として, 地域で難病療養者を支援する保健, 医療, 福祉従事者に対する研修会の企画・運営および講 師, 保健所保健師の事例検討会への参加, 訪問看護久 テーション等の実態把握の活動は, 地域における難病療 養者支援サービスについて, 量, 質を確保するために重 要な機能である.さらに, 本事業の活動成果は, 他県での 同事業関係者への講演, 厚生省特定疾患医療従事者研修 会, 関連学会への発表など他の地域へも還元されている.

以上のように, 専門員の活動は本事業の目的である受 入施設の確保にとどまらず, 療養者の病状に合わせた適 時適切な療養相談や指導, 拠点病院受診者への専門的な 外来看護, 地域の関係機関との有機的な連携と地域ケア 力の向上, といった幅広い役割を果たし, 神経難病医療 連絡協議会が難病療養者のニーズに対応するシステムと して機能していくことを強化している. 専門員が神経難 病看護に精通している看護職であること, 県内の神経難 
病医療の拠点である大学病院神経内科外来に設置されて いることにより，その調整機能は有効に発揮されるもの と考える.

今後の課題は, 相談者や支援機関からの評価の検討を 含め専門員の活動実績を追跡し，抽出された機能の維 持・強化を図ること, 神経難病以外の特殊な看護ケアを 必要とする療養者の広域的な看護相談，および地域連携 システムへと発展させることである.

(本研究は, 平成 12 年度〜平成 13 年度厚生科学研究費 補助金特定疾患対策研究事業横断的基盤研究 特定疾患 患者の生活の質 $(\mathrm{QOL})$ の向上に関する研究班の研究補 助金により行った.)

\section{文献}

1. 厚生統計協会 : 国民衛生の動向. 厚生の指標 臨時増 刊. $2001 ； 48$ (9) : 150-155.

2. 公衆衛生審議会成人病難病対策部会難病対策専門委 員会. 最終報告. 厚生労働省健康局疾病対策課：難 病対策提要, 2001 : 357-365.

3. 公衆衛生審議会成人病難病対策部会難病対策専門委 員会. 今後の難病対策の具体的方向について (報告). 厚生労働省健康局疾病対策課: 難病対策提要, 2001 : 367-376.

4. 吉良潤一. 福岡県における重症神経難病患者入院施 設確保事業の展開 (第 2 報). 特定疾患対策研究事業 特定疾患対策の地域支援ネットワークの構築に関す る研究班 2000 年度研究報告書, 2001：131.

5. 系井泰人, 小野寺宏, 関本聖子ら. 宮城県神経難病医 療連絡協議会の活動一現状についての報告と今後の 展望について. 特定疾患対策研究事業 特定疾患対 策の地域支援ネットワークの構築に関する研究班 2000 年度研究報告書, 2001：33-38.

6. 牛込三和子, 友松幸子, 飯田苗恵ら. 神経難病医療 ネットワークにおける難病医療専門員 (看護職) の コーディネート機能. 特定疾患対策研究事業 特定
疾患患者の生活の質 $(\mathrm{QOL})$ の向上に関する研究班 平成 12 年度研究報告書, $2001: 218-224$.

7. 岩木三保, 武藤香織, 吉良潤一ら. 難病医療専門員に よる相談業務とサポートの在り方について．日難病 看会誌 $1999 ； 4 ： 39$.

8. 関本聖子. 神経難病患者療養手帳作成の試み。日難 病看会誌 $2001 ； 5 ： 193-197$.

9. 川村佐和子, 廣瀬和彦, 近藤紀子ら. 難病の地域ケ ア・システムの類型化に関する研究. 厚生省特定疾 患「難病のケア・システム」調査研究班 平成 3 年 度研究報告, 1992：411-412.

10. 川村佐和子, 廣瀬和彦, 近藤紀子ら. 難病の地域ケ ア・システムの類型化に関する研究第 2 報. 厚生省 特定疾患「難病のケア・システム」調査研究班 平 成 4 年度研究報告, 1993：44-47.

11. 群馬県保健福祉部保健予防課. 平成 11 年度群馬県 神経難病医療ネットワーク推進事業活動報告書, 2000 : 39-41.

12. 早川映理, 牛久保美津子, 川村佐和子ら. 東京都難病 医療相談事業の 7 年間の活動の分析. 日プライマ リ・ケア会誌 $2001 ； 24$ (3)：189-196.

13. 宮塚映理, 川村佐和子, 数間恵子ら. 広域的な難病医 療相談の機能に関する研究一その機能と看護の専門 的役割について. 日公衛誌 $1997 ; 44$ (10) 特別附 録： 550 .

14. Rhoda R, Hiroshi Mitsumoto. A comprehensive approach to managing amyotrophic lateral sclerosis. In: Hiroshi Mitsumoto, Theodore L. Munsat. Amyotrophic lateral sclerosis A guide for patients and families. New York: Demos Medical Publising, $2001: 63-77$.

15. Hiroshi Mitsumoto, David A. Chad, Erik P. Pioro. Comprehensive care. In : Amyotrophic Lateral Sclerosis. Philadelphia: F. A. DAVIS COMPANY, 1998: 305-318. 


\title{
Activities and Functions of the Nurse Coordinator in the Network for Intractable Neurological Diseases
}

\author{
Miwako Ushigome, ${ }^{1}$ Sachiko Tomomatsu, ${ }^{2}$ Kyoko Sasaki, ${ }^{1}$ \\ Mitsue Iida, ${ }^{3}$ Koichi Okamoto, ${ }^{4}$ Yuko Yoda, ${ }^{5}$ \\ Yoshikiyo Kobayashi, ${ }^{6}$ and Chieko Saotome ${ }^{5}$ \\ 1 School of Health Sciences, Faculty of Medicine, Gunma University, Maebashi, Gunma 371-8511, Japan \\ 2 Coordinator in Gunma Prefectural Network for Intractable Neurological Diseases, Maebashi, Gunma 371- \\ 8511, Japan \\ 3 Department of Nursing, Gunma Prefectural College of Health Sciences, Maebashi, Gunma 371-0052, Japan \\ 4 Department of Neurology, Faculty of Medicine, Gunma University, Maebashi, Gunma 371-8511, Japan \\ 5 Health Management Division, Department of Health and Welfare, Gunma Prefecture, Maebashi, Gunma \\ 371-8570, Japan \\ 6 Nakanojo Health and Welfare Office, Gunma Prefecture, Agatsuma, Gunma 377-0425, Japan
}

Background: For patients with severe intractable neurological diseases such as amyotrophic lateral sclerosis (ALS) to be hospitalized when their conditions become worse, the Gunma prefectural government established a network of 65 hospitals in 1999. A nurse coordinator has been assigned to the Department of Neurology at the Gunma University Hospital, the center hospital for the network.

Objectives and Methods: We analyzed records the coordinator kept from 1999 to 2001 and classified coordinating activities in this network.

Results and Conclusions: The coordinator responded to 601 consultations on 246 patients given by patients, their families, public health nurses, and doctors. Coordinating activities were classified into 5 categories : giving specialized and specific advice at each consultation, coordinating patient, hospitalization following up patients at the center hospital and coordinate local services, supporting patients followed by public health centers and enlarging local care capacity through activities such as studies and seminars. We found that the coordinator at the center hospital has been functioning very well in this network. Coordinators such as those in this network are indispensable for sound care systems for intractable neurological diseases. (Kitakanto Med J 2002; $52: 243 \sim 252$ )

Key words : nurse coordinator, intractable diseases, neurological patients, center hospital, social support system 